\title{
РАЗВИТИЕ И СОВРЕМЕННОЕ ПОЛОЖЕНИЕ ПРИНЦИПА РАЗУМНОГО СРОКА УГОЛОВНОГО СУДОПРОИЗВОДСТВА
}

\author{
(C) 2021 Шпак Анастасия Александровна \\ магистрант Юридической школы ДВФУ, \\ 40.04.01 «Юриспруденция» программа «Юрист в сфере публичного права» \\ Дальневосточный федеральный университет, Россия, Владивосток \\ E-mail: anastasiya-shpak98@mail.ru \\ (C) 2021 Шахова Анастасия Максимовна \\ магистрант Юридической школы ДВФУ, \\ 40.04.01 «Юриспруденция» программа «Юрист в сфере публичного права» \\ Дальневосточный федеральный университет, Россия, Владивосток \\ E-mail: nastiaaleshk@mail.ru

\section{(c) 2021 Шахов Никита Владимирович} \\ магистрант Юридической школы ДВФУ, \\ 40.04.01 «Юриспруденция» программа «Юрист в сфере публичного права» \\ Дальневосточный федеральный университет, Россия, Владивосток \\ E-mail: shahovnik@mail.ru
}

Любой процесс неразрывно связан с определенными временными периодами. Для уголовного процесса также установлены специальные сроки, которым должны соответствовать действия его участников. Данная статья посвящена важнейшему для уголовного процесса требованию разумности сроков судопроизводства. Доказан принципиальный характер этого требования и пояснена его связь с иными принципами уголовного процесса.

Ключевые слова: принципы права, уголовный процесс, уголовное судопроизводство, разумный срок судопроизводства, права человека.

Прежде, чем переходить непосредственно к анализу заявленной темы исследования, следует напомнить с тем, что из себя представляют принципы права. В соответствии с общими нормами русского языка одно из значений слова «принцип» - основное, исходное положение какой-либо теории, учения, мировоззрения, теоретической программы. Хотя данное общеупотребительное значение не вполне подходит для сферы юриспруденции, тем не менее, оно выражает сущность этого теоретического явления: принципы - это основы.

Чтобы уяснить, что такое принципы права, можно обратиться к трудам наиболее выдающихся ученых в области теории государства и права. Так, В.С.Нерсесянц подразумевает под ними общие начала и смысл права [5, С. 494]. Н.И.Матузов и А.В.Малько утверждают, что принципы права - это основные, исходные начала, положения, идеи, выражающие сущность права как специфического социального регулятора, воплощающие его закономерности, при- роду и социальное назначение. Они представляют собой наиболее общие правила поведения, которые либо прямо сформулированы в законе, либо выводятся из его смысла [3, С. 82]. Очевидно, что данная категория подразумевает определенные общие начала, пронизывающие все право и (или) его отдельные структурные элементы.

Соответственно отрасль уголовно-процессуального права также имеет свои принципы - то есть юридически оформленные руководящие положения, закрепляющие наиболее общие и существенные свойства уголовного процесса, которые выражают его природу, социальную сущность и направленность, определяют основные правила уголовно-процессуальной деятельности [13, С. 61]. Традиционно принято считать, что они закреплены в главе 2 Уголовнопроцессуального кодекса Российской Федерации от 18.12.2001 № 174-Ф3 (далее по тексту УПК РФ) [14]. Также одна из статей этой главы носит название «Разумный срок уголовного судопроизводства». Казалось бы, это достаточно 
ясно указывает на то, что законодатель воспринимает указанное требование к осуществлению уголовного судопроизводства как принцип уголовного процесса - учитывая его значение для защиты прав и свобод человека и гражданина в демократическом правовом государстве.

Историю этого принципа следует начать с того, что его формулировка была введена в УПК РФ только в 2010 году [6]. Ранее - ни в новом уголовно-процессуальном законе, ни в предшествующем отечественном законодательстве ее не содержалось. Хотя, необходимо отметить, что уже в документах доимперского русского права можно усмотреть государственную защиту права на рассмотрение дела судом в кратчайшие сроки (например, запрет судебной «волокиты» в Судебнике 1497 г. [11]). Нормативно-правовые акты Российской Империи также говорили о «всевозможной скорости» следствия [17]. В советский период правило о соблюдении определенных сроков движения уголовного дела приняло более четкие очертания за счет установления отдельных процессуальных сроков и возможности их продления [15].

В современное уголовно-процессуальное право четкая формулировка «разумный срок уголовного судопроизводства» пришла из международного права. Ее закрепляет Европейская конвенция о защите прав человека и основных свобод (далее по тексту - ЕКПЧ) в ст. 5 и ст. 6 (право на разбирательство дела в разумный срок) [2]. Иные основополагающие акты международного уровня также не оставляют без внимания временную характеристику процесса: Международный пакт о гражданских и политических правах 1966 г. в ст. 14 провозглашает право каждого лица при рассмотрении любого предъявляемого ему уголовного обвинения быть судимым без неоправданной задержки (как одна из минимальных, то есть базовых и неотъемлемых гарантий прав человека) [4].

Кроме того, и в документах, не являющихся нормативно-правовыми актами, принятых на территории Российской Федерации до 2010 года, упоминался разумный срок. В пример можно привести Постановление Пленума Верховного Суда РФ от 27.12.2007 № 52 «О сроках рассмотрения судами Российской Федерации уголовных, гражданских дел и дел об административных правонарушениях», где повторялись положения ЕКПЧ и, к сожалению, не давалось современное определение разумного срока в уголовном про- цессе [8].

Сегодня же разумный срок уголовного судопроизводства - это достаточно дискуссионная категория. Большинство научных исследователей вслед за законодателем признают за этим требованием основополагающий характер принципа уголовного процесса (П.А. Лупинская [12, С. 248], Э. К. Кутуев [13, С. 67] и др.). Тем не менее, так считают не все. Например, А.П. Рыжаков, рассматривая чуть менее 30 выделяемых им (и другими учеными) принципов уголовного судопроизводства, не называет среди них разумный срок (хотя перечисляет принцип неприкосновенности личности, неприкосновенности жилища, принцип обжалования процессуальных действий (бездействия) и решений и др. [10]). Такого же мнения придерживаются Б. Т. Безлепкин [1], О.И. Рабцевич, В.С.Раменская, О.В.Рябкова, Е. В. Салтыков, Т. А. Соловьева [16].

Такую точку зрения достаточно легко опровергнуть. Для этого следует обратиться к признакам (или критериям), которым должны отвечать принципы права: 1) закрепленность в законе, принятом высшим органом законодательной власти, обуславливающая высшую юридическую силу такого базового положения; 2) обеспеченность принудительной силой государства; 3) принцип должен иметь основополагающее значение для всей сферы, на которую предполагается его распространение (в данном случае для всего уголовного процесса), должен определять ее главные черты; 4) принцип как норма должен находиться во взаимосвязи с иными принципами, должен являться элементом их системы, которая, обеспечивает эффективное функционирование уголовного судопроизводства и успешное решение задач уголовного процесса [13, С. 62].

Как уже было сказано, разумный срок уголовного судопроизводства закреплен в УПК РФ - нормативно-правовом акте, федерального значения, принятом высшим органом законодательной власти. На основании того, что любой норме права присуща обеспеченность принудительной силой государства, можно сказать, что и второй критерий для разумного срока выполняется в полной мере. Кроме того, следует обратить внимание на дополнительные гарантии права на рассмотрение уголовных дел в разумные сроки: в том числе, Федеральный закон «О компенсации за нарушение права на судопроизводство в разумный срок или права на 
исполнение судебного акта в разумный срок» от 30.04.2010 № 68-Ф3 [7]. Тот факт, что разумный (адекватный всем нюансам конкретного уголовного дела) срок судопроизводства имеет основополагающее значение также трудно оспорить. Можно привести элементарные примеры его «полезности»: 1) потерпевшие и иные заинтересованные лица со стороны обвинения могут рассчитывать на своевременную защиту их прав пока такая защита эффективна и необходима; 2) подозреваемый, обвиняемый, подсудимый не находятся в «состоянии неопределенности» своей судьбы необоснованно длительное время, так как обратное может серьезно нарушить их права (сказаться на их физическом и психическом здоровье, экономическом состоянии); 3) уголовные дела не накапливаются, не создается дополнительная нагрузка для органов предварительного расследования и суда; 4) иные, невластные, участники процесса, не связанные со сторонами, также не находятся в «подвешенном состоянии», слишком долго ожидая, когда наступит время их участия в процессе.

Следовательно, уже можно сделать вывод о наличии такого принципа уголовного процесса и определить его связь с иными принципами - в качестве последнего доказательства равнозначного им характера.

Во-первых, исходя из деления процессуальных принципов на организационные (судоустройственные) и функциональные (судопроизводственные) [13, С. 64] необходимо классифицировать его - прежде всего исходя из наименования - как функциональный принцип - так как он пронизывает и определяет всю процессуальную деятельность.

С принципом законности рассматриваемый принцип связан путем установления правила: осуществление судопроизводства в разумный срок предполагает осуществление досудебного и судебного производства по уголовному делу в установленные законом сроки [9]. Принцип законности (не смотря на равноценность всех принципов) можно назвать главенствующим в любой сфере деятельности правового государства - в том числе в области защиты прав человека и обеспечения правосудия. Следовательно, без принципа законности принцип разумного срока судопроизводства потерял бы смысл своего нормативного закрепления. В целом их соотношение можно определить так: разумный срок должен быть законным (закрепленным в законе, не выходящим за его рамки), а любой процессуальный срок, закрепленный в законе, должен быть разумным, так как только в этом случае будет восстановлена справедливость и эффективно реализованы права и обязанности участников процесса.

С принципом обеспечения подозреваемому и обвиняемому права на защиту разумный срок связан путем установления достаточного (адекватного) временного периода для того, чтобы такие лица могли воспользоваться своим конституционным правом в полной мере, и не были поставлены в заведомо невыгодное положение по отношению к стороне обвинения. Как бы то ни было, подозреваемый (обвиняемый) - прежде всего человек, дополнительной гарантией соблюдения прав которого является закрепление принципа разумного срока. Это вполне соответствует одному из назначений уголовного судопроизводства, закрепленному в п. 2 ч. 1 ст. 6 УПК РФ: защите личности от незаконного и необоснованного обвинения, осуждения, ограничения ее прав и свобод.

Кроме того, не смотря на то, что начало течения разумного срока по-разному определяется для лица, в отношении которого осуществляется уголовное преследование и потерпевшего или иного заинтересованного лица, которому деянием, запрещенным уголовным законом, был причинен вред (ч. 3 ст. 6.1 УПК РФ), его нарушение может (должно) нарушить права как одной, так и другой стороны, в том числе повлиять на выполнение принципа состязательности и равноправия сторон процесса - так как возможны случаи, когда затягивание процесса выгодно для одной из сторон.

Со всеми организационными принципами изучаемый принцип связан следующим образом: если их надлежащее выполнение не будет организовано в срок, то он будет нарушен (например, если дело чрезмерно затянется из-за того, что не был вовремя выяснен и разрешен вопрос о независимом составе суда).

Общим же правилом, определяющим соотношение и взаимодействие рассматриваемого принципа с иными принципами уголовного процесса является следующее: принцип разумного срока подразумевает требование к периоду времени, в который должны быть реализованы все иные принципы; он не может быть нарушен ради выполнения других принципов и ни один принцип уголовного процесса не может нару- 
шаться ради соблюдения разумного срока.

Таким образом, можно сделать вывод, что необходимость соблюдения разумного срока уголовного судопроизводства является исторически сложившимся основным началом (принципом), которому должны быть подчинены все процессы, опосредующие законное и справед- ливое разрешение каждого уголовного дела. Без его соблюдения теряется смысл производимых участниками судопроизводства действий, а также недостижима цель обеспечения достойной реализации и защиты прав и свобод человека и гражданина в современном правовом демократическом государстве.

\section{Библиографический список}

1. Безлепкин Б.Т. Уголовный процесс в вопросах и ответах: учебное пособие (8-е изд., перераб. и доп.) / Б. Т. Безлепкин. Москва: Проспект, 2016. - Доступ из СПС «Гарант».- Текст: электронный.

2. Конвенция о защите прав человека и основных свобод (Заключена в г. Риме 04.11.1950) (с изм. от 24.06.2013) (вместе с Протоколом [№ 1] (Подписан в г. Париже 20.03.1952), Протоколом № 4 об обеспечении некоторых прав и свобод помимо тех, которые уже включены в Конвенцию и первый Протокол к ней (Подписан в г. Страсбурге 16.09.1963), Протоколом № 7 (Подписан в г. Страсбурге 22.11.1984)).- Доступ из СПС «КонсультантПлюс».-Текст: электронный.

3. Малько А. В. Теория государства и права: учебник / А. В. Малько, Н. И. Матузов. Юристъ, 2004. 512 с.

4. Международный пакт о гражданских и политических правах (Принят 16.12.1966 Резолюцией 2200 (XXI) на 1496-м пленарном заседании Генеральной Ассамблеи ООН). - Доступ из СПС «КонсультантПлюс».- Текст: электронный.

5. Нерсесянц В.С. Общая теория права и государства: учебник / В.С. Нерсесянц. Москва: Норма: ИНФРА-М, 2012. $560 \mathrm{c}$.

6. О внесении изменений в отдельные законодательные акты Российской Федерации в связи с принятием Федерального закона «О компенсации за нарушение права на судопроизводство в разумный срок или права на исполнение судебного акта в разумный срок»: Федеральный закон от 30.04.2010 № 69-ФЗ (ред. от 08.03.2015). - Доступ из СПС «КонсультантПлюс».- Текст: электронный.

7. О компенсации за нарушение права на судопроизводство в разумный срок или права на исполнение судебного акта в разумный срок: федеральный закон от 30.04.2010 № 68-Ф3 (ред. от 19.12.2016). - Доступ из СПС «КонсультантПлюс».- Текст: электронный.

8. О сроках рассмотрения судами Российской Федерации уголовных, гражданских дел и дел об административных правонарушениях: постановление Пленума Верховного Суда РФ от 27.12.2007 № 52 (ред. от 09.02.2012). - Доступ из СПС «КонсультантПлюс».- Текст: электронный.

9. По делу о проверке конституционности положений части 1 статьи 1 Федерального закона «О компенсации за нарушение права на судопроизводство в разумный срок или права на исполнение судебного акта в разумный срок» и части третьей статьи 6.1 Уголовно-процессуального кодекса Российской Федерации в связи с жалобами граждан В.В. Курочкина, А. Б. Михайлова и А.С. Русинова: постановление Конституционного Суда РФ от 11.11.2014 № 28-П.- Доступ из СПС «КонсультантПлюс».- Текст: электронный.

10. Рыжаков А.П. Уголовный процесс: учебник для вузов (11-е издан. испр. и доп.) / А.П.Рыжаков. Москва, 2017. - Доступ из СПС «Гарант». - Текст: электронный.

11. Судебник 1497 г. // Российская юстиция. 2006. № 11.- Доступ из СПС «Гарант».- Текст: электронный.

12. Уголовно-процессуальное право Российской Федерации: учебник / отв. ред. П. А. Лупинская, Л. А. Воскобитова. 3-е изд., перераб. и доп. Москва: Норма: ИНФРА-М, 2013. 1008 с.

13. Уголовно-процессуальное право (Уголовный процесс): Учебник для вузов / Под ред. проф. Э. К. Кутуева; науч. ред. и вступительное слово проф. В.П.Сальникова; 2-е изд., перераб. и доп. Санкт-Петербург: СанктПетербургский ун-т МВД России; Фонд «Университет», 2019. 583 с.

14. Уголовно-процессуальный кодекс Российской Федерации: федеральный закон от 18.12.2001 № 174-Ф3 (ред. от 01.07.2021). - Доступ из СПС «КонсультантПлюс».- Текст: электронный.

15. Уголовно-процессуальный кодекс РСФСР (утв. ВС РСФСР 27.10.1960) (ред. от 29.12.2001, с изм. от 26.11.2002) (с изм. и доп., вступающими в силу с 01.07.2002).- Доступ из СПС «КонсультантПлюс».- Текст: электронный.

16. Уголовный процесс: учебник / О.И.Рабцевич [и др.]; под ред.д.ю.н., проф. В.С.Балакшина, к.ю.н., доц. Ю.В.Козубенко, д.ю.н., проф. А.Д.Прошлякова. Инфотропик Медиа, 2016.- Доступ из СПС «Гарант».Текст: электронный.

17. Устав уголовного судопроизводства от 20 ноября 1864 г. - Доступ из СПС «Гарант».- Текст: электронный. 